\title{
Debris Removal by Activation of Endodontic Irrigants in Complex Root Canal Systems: A Standardized In-Vitro-Study
}

\author{
Matthias Widbiller ${ }^{1, *} \mathbb{( \mathbb { D }}$, Lukas Keim ${ }^{1}$, Ralf Schlichting ${ }^{2}$, Birgit Striegl ${ }^{3}$, Karl-Anton Hiller ${ }^{1}$, \\ Rebecca Jungbauer ${ }^{4}$, Wolfgang Buchalla ${ }^{1}$ and Kerstin M. Galler ${ }^{1}$ \\ 1 Department of Conservative Dentistry and Periodontology, University Hospital Regensburg, \\ 93053 Regensburg, Germany; lukas.keim@ukr.de (L.K.); karl-anton.hiller@ukr.de (K.-A.H.); \\ wolfgang.buchalla@ukr.de (W.B.); kerstin.galler@ukr.de (K.M.G.) \\ 2 Independent Researcher, 94032 Passau, Germany; dr.schlichting@icloud.com \\ 3 Department of Biomedical Engineering, Technical University of Applied Sciences (OTH), \\ 15745 Regensburg, Germany; birgit.striegl@oth-regensburg.de \\ 4 Department of Orthodontics, University Hospital Regensburg, 93053 Regensburg, Germany; \\ rebecca.jungbauer@ukr.de \\ * Correspondence: matthias.widbiller@ukr.de; Tel.: +49-941-9446024
}

check for updates

Citation: Widbiller, M.; Keim, L.; Schlichting, R.; Striegl, B.; Hiller, K.-A.; Jungbauer, R.; Buchalla, W.; Galler, K.M. Debris Removal by Activation of Endodontic Irrigants in Complex Root Canal Systems: A Standardized In-Vitro-Study. Appl. Sci. 2021, 11, 7331. https://doi.org/ 10.3390/app11167331

Academic Editor: Luca Testarelli

Received: 8 July 2021

Accepted: 6 August 2021

Published: 9 August 2021

Publisher's Note: MDPI stays neutral with regard to jurisdictional claims in published maps and institutional affiliations.

Copyright: (c) 2021 by the authors. Licensee MDPI, Basel, Switzerland. This article is an open access article distributed under the terms and conditions of the Creative Commons Attribution (CC BY) license (https:// creativecommons.org/licenses/by/ $4.0 /)$.

\begin{abstract}
Aim of the study was to develop a standardized model system to investigate endodontic irrigation techniques and assess the efficiency of different activation methods on the removal of hard tissue debris in complex root canal systems. Mesial roots of mandibular molars were firstly scanned by micro-computed tomography $(\mu \mathrm{CT})$ and allocated to three groups of irrigant activation: sonic activation (EDDY, VDW, Munich, Germany), laser activation (AutoSWEEPS, FOTONA, Ljubljana, Slovenia) and conventional needle irrigation (control). Roots were fixed in individual 3D-printed holders to facilitate root canal enlargement under constant irrigation with $\mathrm{NaOCl}(5 \%)$. To enable standardized quantification of remaining debris, $\mathrm{BaSO}_{4}$-enriched dentine powder was compacted into the canals, followed by another $\mu \mathrm{CT}$-scan. The final irrigation was performed using $17 \%$ ethylenediaminetetraacetic acid (EDTA) and 5\% sodium hypochlorite $(\mathrm{NaOCl})$ with the respective activation method, and the volume of remaining artificial debris was quantified after a final $\mu \mathrm{CT}$-scan. The newly developed model system allowed for reliable, reproducible and standardized assessment of irrigation methods. Activation of the irrigant proved to be significantly more effective than conventional needle irrigation regarding the removal of debris, which persisted particularly in the apical third of the root canal in the control group. The efficiency of irrigation was significantly enhanced with laser- and sonic-based activation, especially in the apical third.
\end{abstract}

Keywords: disinfection; sodium hypochlorite; ethylenediaminetetraacetic acid; lasers; computed tomography

\section{Introduction}

Caries, dental trauma and tooth malformations frequently cause an infection of the dental pulp, which results, if untreated, in pulpitis, pulp necrosis and, finally, apical periodontitis. In this case, root canal treatment (RCT) is indicated, as the removal of necrotic pulp tissue and bacteria from the entire canal system enables healing of periapical pathosis [1-3]. During RCT, the endodontic canal system has to be explored, and the canals are enlarged and debrided by endodontic files. However, mere mechanical instrumentation results in insufficient cleanliness, as up to one-third of the canal surface remains untouched [4-6]. Furthermore, accumulated hard tissue debris (AHTD) during treatment locks isthmuses and lateral canals and, thus, impedes the transport of irrigant into these areas [1]. Therefore, there is a demand for copious irrigation to support mechanical instrumentation and dissolve debris. Sodium hypochlorite $(\mathrm{NaOCl})$ has proven to be very effective, as it has both antibacterial and tissue-dissolving features [7]. If applied by needle 
irrigation only, thorough cleaning and disinfection of isthmuses, lateral canals and the apical segment of root canals fails [8-11]. In addition, the endodontium can be considered a closed-end-system; thus, air is trapped in the apical region during irrigation, which prevents the penetration of disinfectant even further [12,13]. For this reason, various activation methods have been developed to optimize the penetration of disinfecting agents into the root canal system and enhance the removal of AHTD [14].

Several different activation methods are available to the endodontist. Among them, the sonic-based activation system EDDY (VDW, Munich, Germany) uses a polyamide tip, which oscillates at a frequency of $6 \mathrm{kHz}$. These oscillations create turbulences in the surrounding disinfecting solution, supposedly resulting in removal of AHTD and disruption of intracanal biofilm [15]. Various studies have reported sonic activation to be more effective than needle irrigation in terms of AHTD elimination [16-21].

In recent years, newly developed laser systems have enabled the activation of disinfectants by photon-induced photoacoustic streaming (PIPS, FOTONA, Ljubljana, Slovenia). This method seems to be advantageous when cleaning confined spaces [22], where (ultra)sonic-based systems are considered less effective due to limited space for oscillation [23]. In addition, curvatures hinder the distribution of (ultra)sonic energy in the root canal [24], and rigid tips can damage dentine walls and thus alter the shape of the canal $[25,26]$.

Previous studies have shown that PIPS offers advantages over conventional needle irrigation and passive ultrasonic activation regarding removal of debris and the smear layer, as well as antibacterial effects [27-29]. Recently, a PIPS derivative, termed shockwave enhanced emission photoacoustic streaming (SWEEPS), has been introduced to the market. An Er:YAG laser emits pulsed light at a wavelength of $2940 \mathrm{~nm}$ through a fiberglass tip, which transfers the light into the surrounding disinfection solution. Due to the high absorption of clear liquids at this wavelength, heat is generated locally and causes spontaneous evaporation at the tip. The resulting gas bubbles collapse and trigger shock waves that generate smaller secondary bubbles. In contrast to PIPS, SWEEPS emits two subsequent laser pulses. The timing is adjusted such that the second pulse is emitted at the time the gas bubble from the first pulse collapses. As a result, the first bubble is pushed deeper into the root canal, and secondary bubbles collapse due to the additional pressure [30]. This chain reaction may continue along the entire length of the root canal to cause microstreaming and, thus, increase the penetration depth of the disinfectant [30]. Lukač et al. suspected that the velocity at which bubbles collapse during PIPS is too slow to generate effective shock waves in narrow root canals due to friction along the canal wall; however, SWEEPS facilitates an accelerated collapse and thus generates more shock waves [30]. Whereas the first SWEEPS system appeared to be inferior to PIPS regarding the penetration depth of the irrigation solution in root canals with simple anatomy [31], a technically improved version, called AutoSWEEPS, was released shortly after [32]. Wang et al. observed improved bacterial clearance of Enterococcus faecalis in palatal roots of maxillary first molars using AutoSWEEPS when compared to PIPS [33]. However, previous investigations based their studies on easily accessible root canal geometries, which do not reflect complex configurations, such as isthmuses or branching canals.

Currently, studies on innovative activation techniques such as AutoSWEEPS are sparse and often afflicted with considerable shortcomings in terms of methodology and standardization [34]. In particular, variations in irrigation parameters (volume, time, flow rate, etc.) and in debris formation, but also insufficient quantification methodology, hamper the comparability of groups within a study as well as between different studies.

Multiple endodontic studies with a wide range of questions have been based on the technology of $\mu \mathrm{CT}$-imaging $[35,36]$. It is a highly precise tomographic method that allows specimens to be examined non-destructively and, thus, repeatedly and to make clear metric determinations, e.g., volume measurements. However, the quantitative determination of volumes is often dependent on a subjective and manual definition of regions of inter- 
est, which may be a source of errors, particularly in the case of structures with similar radiographical densities, such as dentine and AHTD.

To overcome the outlined methodical difficulties and to allow an objective comparison of the described activation techniques, two objectives were addressed in this study: (i) to develop a new model system for root canal irrigation, which introduces standardized irrigation as well as insertion and compaction of artificial debris and, thus, allows for more reliable quantification of debris removal; (ii) to assess the efficiency of debris removal by conventional needle irrigation (CNI) compared to sonic-activated irrigation (SAI) with EDDY and laser-activated irrigation (LAI) with AutoSWEEPS in this model system by means of $\mu \mathrm{CT}$-imaging.

\section{Materials and Methods}

\subsection{Sample Preparation and Volumetric Measurement}

Mesial roots of 45 extracted mandibular molars were collected with informed consent of the donors and approval by the ethics committee of the University of Regensburg (No. 19-1327-101, Ethics Committee, University of Regensburg). Criteria for inclusion were the absence of caries, complete root formation and patency of the root canals. To evaluate the canal anatomy, the root length was adjusted to $10 \mathrm{~mm}$ and high resolution $\mu \mathrm{CT}$-scans were conducted (Phoenix v I tome I xs 240/180, Baker Hughes Digital Solutions, Houston, TX, USA). Three-dimensional reconstructions were generated at a voxel size of $12 \mu \mathrm{m}$. The scans were performed with the D-Tube in "fast scan"-mode and a $0.1 \mathrm{~mm}$ copper filter, resulting in 2000 slices per sample. The detection limit for debris was set to $0.01 \mathrm{~mm}^{3}$, which was determined with test bodies in preceding accuracy measurements.

All roots were classified according to the criteria of Vertucci et al. [37], and the root canal volume was quantified. For data acquisition and 3D-reconstruction, phoenix datos $\mid x$ 2 software (Version 2.5.1, Baker Hughes Digital Solutions) was used. Moreover, volumetric analysis was performed using VG Studio Max software (Version 2.2.3, Volume Graphics, Heidelberg, Germany). The volume of interest (VOI) was defined from the coronal separating plane to the apical endpoint, which was determined with a hand file ISO 15 (K-files, VDW, Munich, Germany), $1 \mathrm{~mm}$ short of the anatomical root length. The length determination of the VOI was performed manually between the determined points with an accuracy of $\pm 0.1 \mathrm{~mm}$ in VG Studio Max software. Together with the outer contour of the roots, the VOI was defined. The resulting 3D-structure was subdivided into three compartments of equal height for further analysis. The $\mu \mathrm{CT}$-scans and their processing were conducted by a trained professional (BS); data analyses were performed by two experienced evaluators (LK, MW). Subsequently, samples were allocated to three experimental groups (CNI, SAI, LAI) and stratified according to their volume and anatomical classification $(n=15)$.

\subsection{Production of 3D-Printed Irrigation Models}

In order to facilitate sample fixation and standardized irrigation, a holding device was produced for each individual root sample based on the initial $\mu \mathrm{CT}$-scans. The two-piece plug system (Figure 1a) was designed with the CAD software Onshape (PTC, Boston, MA, USA). Individually shaped openings were created in the upper part to match the outer contour of the respective root sample (Figure 1b) by use of a boolean operator tool (Blender, Version 2.79b, Stichting Blender Foundation, Amsterdam, The Netherlands) to ensure a perfect fit during handling (Figure 1c). In addition, the upper part was equipped with hose connections for the flow of irrigants via a syringe pump and suction by a dental unit (Figure 1d). Detailed construction plans can be accessed in Figure S1.

Subsequently, the devices were printed in a poly-jet printing process (Objet30 Dental Prime, Stratasys, Eden Prairie, MN, USA) in high-speed mode (28-micron resolution) using VeroGlaze MED620 with SUP705 support material (Stratasys). After 3D-printing and cleaning of the objects, the roots were placed in the respective openings; the lower part was filled with an impression material (Silagum, DMG, Hamburg, Germany) and 
connected to the upper part such that the root tip was fixed and the apical foramen was sealed tightly [38].
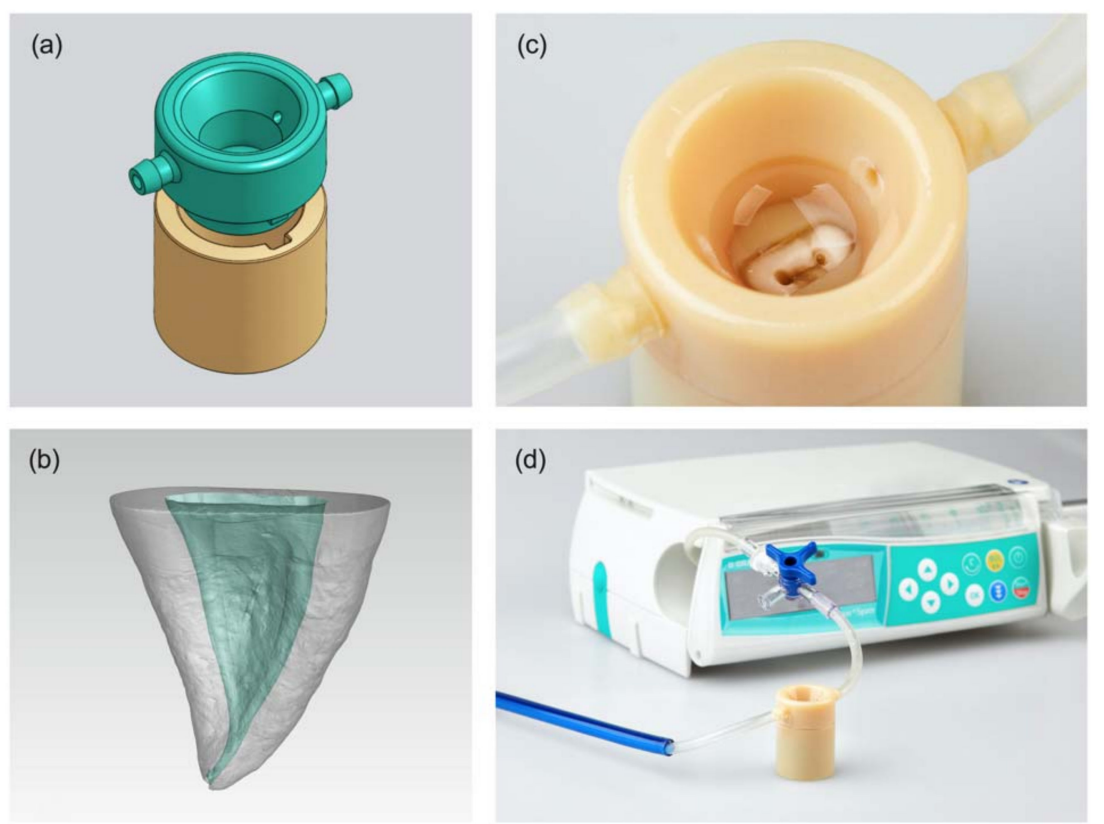

Figure 1. (a) CAD model of the holding and rinsing device, consisting of an upper part (mint) and a lower part (ocher), which were connected via a plug connection. (b) $\mu$ CT-scan of the mesial root of a mandibular molar with isthmus area after root canal preparation. This data was used to create the individual opening in the respective holding device. (c) Tight fit of the root sample in the upper part, enabling good sealing of the reservoir and stable fixation of the sample during manipulation. (d) Experimental setup with the syringe pump for irrigant supplies, as well as the saliva ejector for irrigant aspiration, connected to the rinsing device via infusion tubes.

\subsection{Root Canal Preparation and Introduction of Artificial Debris}

Following glidepath preparation with K-files to size 20.02 (VDW), both mesial root canals were instrumented with rotary files to size 30.07 (Protaper Next X1 to X3, Dentsply Sirona, York, PA, USA). After each use of files, the root canals were rinsed with $\mathrm{NaOCl}$ ( $5 \%, 1 \mathrm{~mL}$, preheated to $60^{\circ} \mathrm{C}$; SPEIKO, Münster, Germany). The irrigating solution was introduced by a 30-gauge double-side-vented needle (Endo irrigation needle, Transcodent, Kiel, Germany) that was inserted $1 \mathrm{~mm}$ short of working length, and a syringe pump created a flow rate of $1 \mathrm{~mL} / \mathrm{min}$ (Orchestra Module DPS, Fresenius Vial Infusion Technology, Brezins, France). All endodontic procedures were carried out using a surgical microscope (PROergo, Carl Zeiss Surgical, Oberkochen, Germany). Subsequently, excess liquid was removed with paper points, and a second $\mu \mathrm{CT}$-scan was carried out as described above.

During pilot experiments, it was observed that already copious irrigation without activation led to nearly complete removal of debris. In order to enable a standardized test system for the different activation techniques, an artificial hard tissue debris model was developed. For this purpose, dentine powder from human molars was fabricated as described previously [39]. Therefore, enamel and root cementum were removed by a diamond bur, and the pulp tissue was separated from the teeth after cracking. Subsequently, dentine was ground using a mixer mill (Mixer Mill MM 200, RETSCH, Haan, Germany). The resulting powder was cleared of particles larger than $50 \mu \mathrm{m}$ by sieving (Stainless-Steel Test Sieve $50 \mu \mathrm{m}$, Thermo Fisher Scientific, Waltham, MA, USA) and mixed with $\mathrm{NaOCl}$ as well as $15 \mathrm{wt} \% \mathrm{BaSO}_{4}$ (Sigma-Aldrich, Steinheim, Germany) to a homogenous, paste-like consistency. The artificial debris was applied to the root canals with a lentulo (Dentsply Sirona) and compacted with two simultaneously inserted guttapercha points (Protaper Next X3, Dentsply Sirona) until full working length was reached. This procedure ensured 
that isthmuses were blocked with debris, but the canal lumina were kept open, which allowed for regular action of irrigants and activation systems (Figure 2). Excess liquid was removed with paper points (Protaper Next X3, Dentsply Sirona), and the canal orifice was sealed with PTFE tape (Scotch 4702, 3M, St. Paul, MI, USA). The teeth were stored moist in Bijou-Tubes (Sterilin $7 \mathrm{~mL}$ Bijou tube, Thermo Fisher Scientific). A third $\mu \mathrm{CT}$-scan was performed to quantify the amount of artificial debris and verify blockage of the isthmus and lateral canals. Due to the distinct difference in radiographical density between the artificial debris containing $\mathrm{BaSO}_{4}$ and normal dentine, a clear and simple discrimination was possible during image processing. Therefore, a histogram with the x-axis showing grey values and the $y$-axis showing the number of voxels was extracted from the $\mu \mathrm{CT}$-scans. Four clearly distinguishable grey scale peaks were obtained for background (air and PTFE), dentin and radiopaque debris. Based on these peaks, distinct grey scale thresholds were defined for all samples for the background (0-0.07), dentin (0.07-0.15) and for radiopaque artificial debris (0.15-0.40). Thus, only the volume of voxels with grey values between 0.15 and 0.40 was quantified in the VG Studio Max software using the "porosity/inclusion analysis (VGDefX/Only threshold)" algorithm.

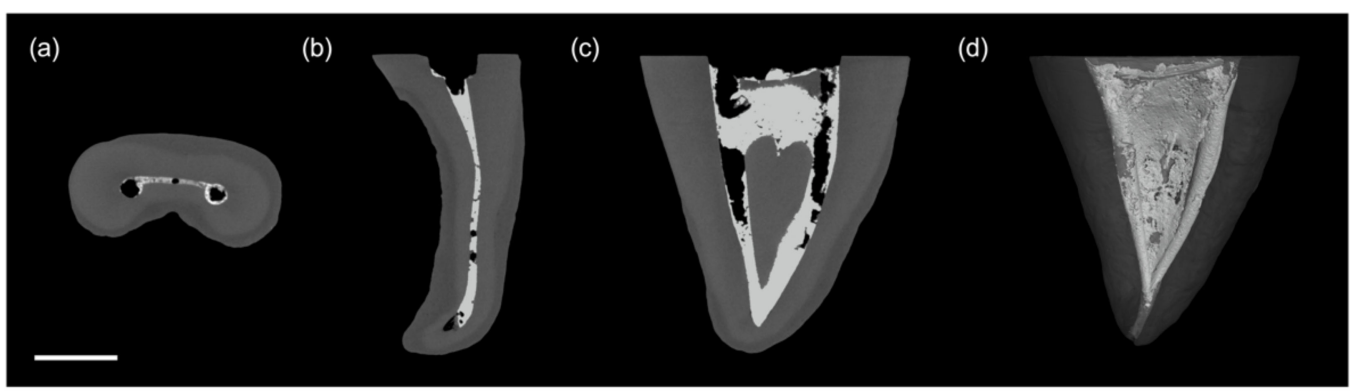

Figure 2. $\mu \mathrm{CT}$-scan of a root sample filled with artificial debris, which appears in light grey color on the root canal walls and in the isthmuses due to its high radiopacity. (a) Axial plane, showing the instrumented root canals and the artificial debris, filling out lateral fins and the entire isthmus area. (b) Sagittal plane of the isthmus, where the artificial debris accumulates in the coronal, middle and apical third. (c) Frontal plane of the root sample. (d) Three-dimensional reconstruction of the artificial dentine debris volume after segmentation from the root sample. Scale bar: $2.5 \mathrm{~mm}$.

\subsection{Final Irrigation and Activation}

Final irrigation to remove artificial debris was performed with and without activation according to a protocol described previously [31]. A syringe pump (Orchestra Module DPS, Fresenius Vial Infusion Technology) was used to standardize irrigant volume, flow rate and contact time with the root canal surface in all experimental steps. The solutions used for the experiments were $5 \% \mathrm{NaOCl}\left(60^{\circ} \mathrm{C}\right)$, ultrapure water (room temperature) and $17 \%$ ethylenediaminetetraacetic acid (EDTA, room temperature). During final irrigation, the following irrigation steps were carried out (Figure S2):

- $5 \mathrm{~mL} \mathrm{NaOCl}$ for $1 \mathrm{~min}$

- $5 \mathrm{~mL}$ ultrapure water for $1 \mathrm{~min}$

- $5 \mathrm{~mL}$ of EDTA for $1 \mathrm{~min}$

- $5 \mathrm{~mL}$ ultrapure water for $1 \mathrm{~min}$

- $5 \mathrm{~mL} \mathrm{NaOCl}$ for $1.5 \mathrm{~min}$ (30 s activation, $30 \mathrm{~s}$ resting phase, followed by $30 \mathrm{~s}$ activation).

The first four steps were performed equally in all experimental groups, with the irrigant coming from a 30-gauge double side vented canula connected to the syringe pump at a constant flow rate. Therefore, the canula was placed $1 \mathrm{~mm}$ short of working length and kept stationary in one canal before it was inserted into the other canal after half of the irrigation. In the fifth step, CNI was performed with a 30-gauge double side vented needle connected to the syringe pump in an up and down motion of $4 \mathrm{~mm}$ amplitude and $1 \mathrm{~mm}$ short of working length. The canula was only inserted into the canals during the two activation intervals but not during the resting phase. In contrast, the irrigant in 
the SAI and LAI groups was supplied by the syringe pump connected to the 3D-printed holding device. Neither for SAI nor LAI was an irrigation needle inserted into the canals. Sonic activation was performed using the EDDY polyamide tip and a sonic handpiece (SONICflex, KAVO Dental, Biberach, Germany) at power setting 3. The polyamide tip was transferred from one canal to the other during the resting phase. In accordance with the manufacturer's instructions, the insertion depth was limited to $1 \mathrm{~mm}$ short of working length, and a gentle up-and-down motion was performed during activation to ensure free movement of the polyamide tip. For laser-activated irrigation, an Er:YAG laser with a R14 handpiece (FOTONA) was used in AutoSWEEPS mode $(20 \mathrm{~mJ}, 15 \mathrm{~Hz}, 0.6 \mathrm{~W}$, water and air cooling turned off). The flat fiberglass tip (Flat SWEEPS 400/9, FOTONA) was inserted into the access cavity filled with $\mathrm{NaOCl}$, and the activation sequence was performed in the same manner as in the other test groups. The experimental sequence ended with a fourth $\mu \mathrm{CT}$-scan to quantify the volume of remaining debris after final irrigation with the thresholding method described above (Figure 3).

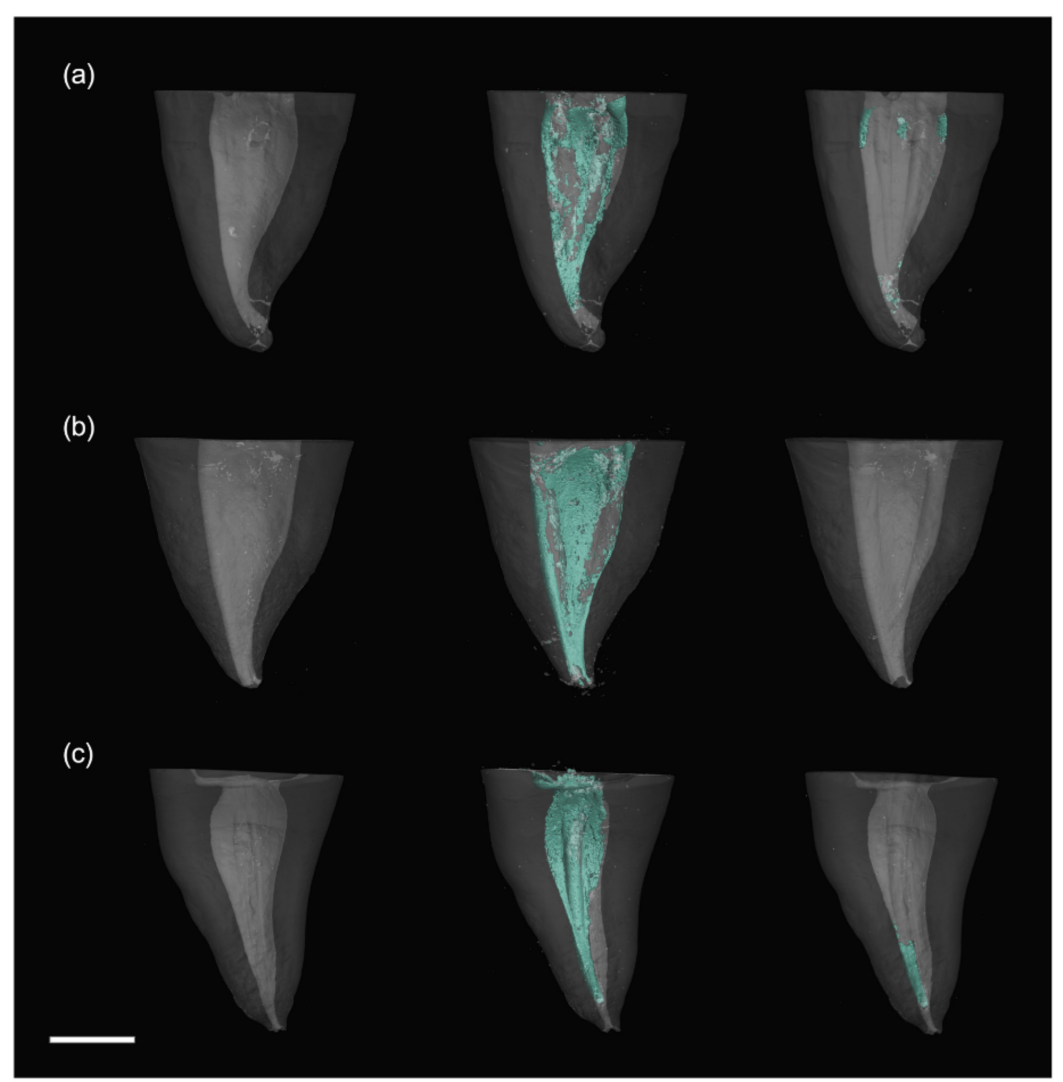

Figure 3. Representative scans of the initial canal system (left), artificial debris (mint) in the instrumented canal (middle) and the endodontium after final irrigation (right). (a) shows conventional needle irrigation with residual debris in the coronal and apical canal; (b) shows sonic-activated irrigation without any debris, and (c) shows laser-activated irrigation with residual debris in the apical third of the canal. Scale bar: $3 \mathrm{~mm}$.

\subsection{Data Treatment and Statistical Analysis}

The following volumes were computed after $\mu \mathrm{CT}$-scans: root canals before and after enlargement, dentine debris after instrumentation and artificial debris before and after final irrigation. Medians and $25-75 \%$ percentiles were calculated for the respective data sets. In addition, the volumes for artificial debris before and after final irrigation were separated into coronal, middle and apical thirds of the root canals to further refine the evaluation of the tested activation methods. 
Data were analyzed statistically by nonparametric tests (Mann-Whitney $U$ ) at a level of significance of $\alpha=0.05$ (SPSS, version 25.0, SPSS, Chicago, IL, USA). $p$-values were adjusted familywise for multiple comparisons by the error rates method (Tables S1-S6).

\section{Results}

\subsection{Formation of AHTD}

As shown in Figure 4a, samples were evenly allocated among the test groups without statistical differences regarding initial root canal volumes $(p>0.595)$. After canal preparation, AHTD was observed in less than $30 \%$ of the samples (Figure $4 \mathrm{a}$ ). The total volume of debris formed was equally low $\left(<0.64 \mathrm{~mm}^{3}\right)$ in all groups $(p>0.436)$.

(a)

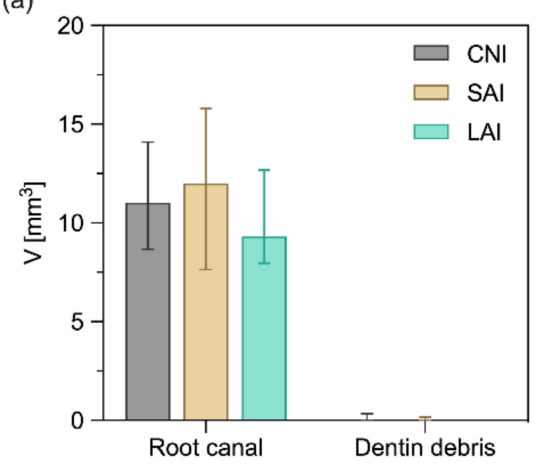

(b)

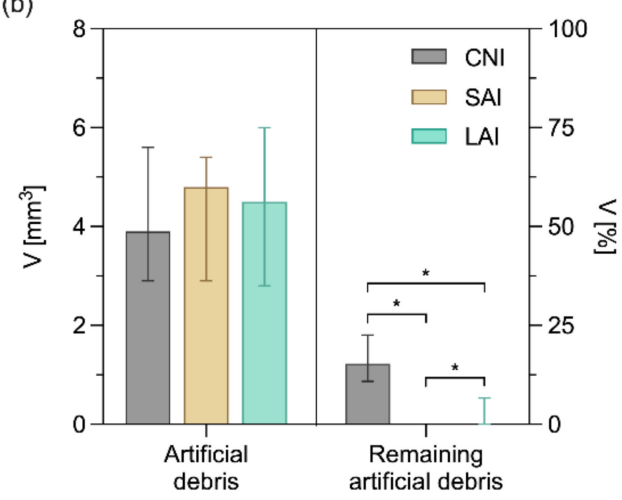

Figure 4. (a) Median root canal volumes with 25-75\% quantiles of the samples and AHTD formation after root canal preparation. (b) Median volume with 25-75\% quantiles of artificial debris in the root canal samples prior to final irrigation and remaining debris after final irrigation. Asterisks denote statistical differences between groups.

\subsection{Insertion and Removal of Artificial Debris}

The insertion of radiopaque artificial debris into the isthmuses and lateral canals was reproducible and resulted in equal volumes, where significant differences between groups could not be detected ( $p>0.713$ ), as shown in Figure $4 \mathrm{~b}$. After final irrigation, a significant reduction of artificial debris volume was observed both for test and control groups. However, significant differences regarding the removal of artificial debris became evident with SAI > LAI $(p=0.029)$ and LAI $>$ CNI $(p=0.000)$.

\subsection{Removal of Artificial Debris in the Individual Root Thirds}

A more specific evaluation of the root segments revealed again equal volume of artificial radiopaque debris in the respective segments (Figure 5a) without significant differences among groups $(p>0.389)$. After final irrigation, significantly more artificial debris was observed in the control group as compared to both activation methods, irrespective of the chosen segment $(p \leq 0.002)$. However, quantification revealed that the highest volumes of artificial debris remained in the apical third (Figure 5b). No statistically significant differences between LAI and SAI were found at the level of root segments $(p>0.174)$. 
(a)

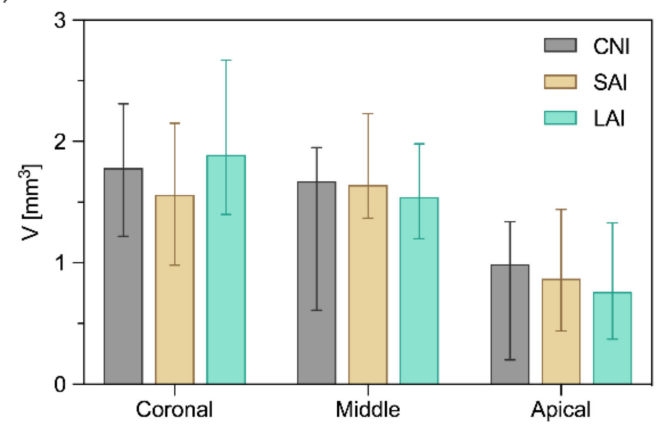

(b)

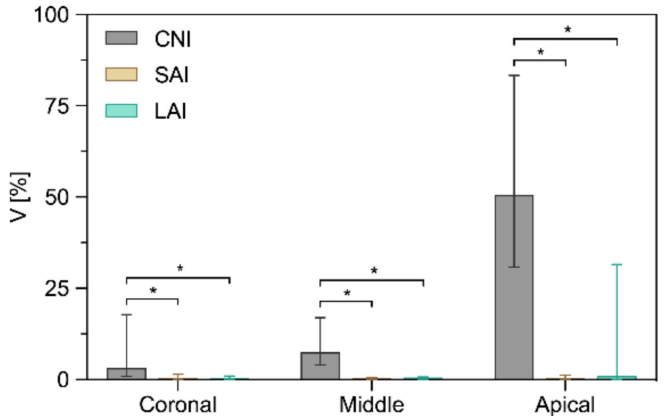

Figure 5. (a) Median volumes with 25-75\% quantiles of artificial dentine debris in the coronal, middle and apical third of the root samples. (b) Median debris volume with 25-75\% quantiles after final irrigation at all levels of the root canal. Asterisks denote statistical differences between groups.

\section{Discussion}

A recent systematic review by Căpută et al. shed light on the lack of standardization in in-vitro-studies investigating the cleaning and disinfection of root canals [34]. An uneven contact time of irrigants with the root canal surface, differences in flow rate of the disinfectant and a variable volume used for irrigation represent imponderables and can alter the reduction of debris [40]. Another point of criticism was a lack of documentation of the power settings for the devices used for activation. Furthermore, it is worth considering the dimensions of the fluid reservoir above the root canal representing the access cavity as well as the detection limit for debris quantification, which may affect the outcomes. Therefore, a major goal of this study was to develop a model system that provides a high level of standardization. The intention was to keep the experimental focus on the research question, whereas uncertainties due to anatomy or debris accumulation, as well as variabilities of the operator in irrigation and activation, should be minimized.

A newly developed, 3D-printed model was used to fasten the roots during processing, which offered the benefit of a standardized reservoir in size of a molar's access cavity that held a defined liquid volume. Differences in irrigation by anatomical variations of the endodontic access in natural teeth were thus avoided. A syringe pump provided a precise flow of liquids during root canal instrumentation and activation sequences. Hose connectors in the 3D-printed device offered the possibilty to rinse the samples during preparation and activation without use of a needle. Thus, alterations by irrigation needles were averted in the SAI and LAI groups.

Another uncertainty is the formation and accumulation of hard tissue debris in root canals. Preliminary experiments have shown that hard tissue debris accumulates unpredictably and forms to a relevant degree when irrigation is kept artificially low [1,32]. However, a thorough disinfection of the root canals during the course of root canal instrumentation prevents accumulation of debris, at least in vitro, as shown in this study. This corresponds to in-vivo-data, describing the absence of hard tissue debris after root canal preparation with ample irrigation [41]. Another reason for the lack of AHTD could be the root canal preparation technique, as rotating multi-file systems, which implement 
a crown-down technique, are known to produce less debris compared to single-file systems [42]. Although these findings highlight the importance of intensive irrigation during instrumentation, an evaluation of activation methods based on those minute amounts of debris is not reasonable. One corrective measure suggested in the literature is the reduction of irrigation efforts to a minimum and, thus, provoking debris formation [1,32]. However, this procedure differs from clinical recommendations, and a standardization of debris formation is not possible. To overcome variations in debris formation and provide similar baseline conditions before final irrigation, an artificial hard tissue debris based on human dentine mixed with sodium hypochlorite and $\mathrm{BaSO}_{4}$ was fabricated, which has not been described before. The focus was to reproduce the consistency of natural AHTD and to achieve similar chemo-mechanical characteristics in the root canal.

Previously, research groups used artificial debris compounded with sodium hypochlorite in a "root-canal-grove model" [43-45]. However, this preclinical model was based on longitudinally dissected teeth with simple root canal morphology that does simulate complex root canal configurations like in mandibular molars. Furthermore, previous $\mu \mathrm{CT}$ studies investigated how irrigation and activation does remove calcium hydroxide from the root canal $[46,47]$. Radiopaque additives, like iodoform or $\mathrm{BaSO}_{4}$, contained in these preparations were clearly differentiable from dentine in $\mu \mathrm{CT}$-images and are thus easy to quantify. On the other hand, calcium hydroxide has different qualities compared to dentine debris and may therefore not be a suitable surrogate in the context of root canal cleaning and disinfection. By combining human dentine powder with both sodium hypochlorite and $\mathrm{BaSO}_{4}$, we were able to unite the advantages of the previous approaches, resulting in debris formation that was technically quantifiable by $\mu \mathrm{CT}$.

Clinically, the formation of AHTD during root canal preparation depends on various parameters, such as canal configuration and diameter, the constitution of isthmuses or the endodontic files and their mode of action [41,42]. In contrast, artificial debris introduced into previously enlarged root canals offers great advantages in terms of standardization. A compaction of artificial debris with guttapercha facilitated homogeneous and consistent filling of isthmuses and voids right up to the apex. In particular the apical third of the canal constitutes a critical region that must be reached by disinfection and activation. In analogy to the results of this study, previous investigators reported AHTD volumes as low as $0.81 \mathrm{~mm}^{3}$ after root canal preparation [48,49]. However, the artificial radiopaque debris filled all voids and isthmuses with a free canal lumen, resulting in a median volume of $4.4 \mathrm{~mm}^{3}$, which presented a greater but equitable challenge for final irrigation.

From a methodical point of view, $\mathrm{BaSO}_{4}$, as a radiopaque additive to artificial debris, simplified optical segmentation in $\mu \mathrm{CT}$-scans at a detection limit of $0.01 \mathrm{~mm}^{3}$ through a clear differentiation from root dentine. Another benefit of this method is the possibility to quantify debris automatically via thresholding. In contrast, previous studies mainly used co-registering and subtractive algorithms to determine the amount of debris, which entails systematic errors and inaccuracies due to multiple offsetting of volumes $[1,22,44]$. In another investigation, acrylic teeth were used for better differentiation; however, this does not correspond to a natural tooth due to differing surface qualities and microanatomy [50].

In terms of endodontic irrigation, $\mathrm{CNI}$ is widely accepted among clinicians, as there is no need for special equipment, and the procedure is easy to integrate in any workflow. Previous research has shown that an up and down motion of the needle in the canal during irrigation supports cleaning the dentine surface from collagen and allows for a better exchange of disinfectant towards the apex [51,52]. However, it is also well accepted that $\mathrm{CNI}$ has shortcomings in regards to cleaning compared to activated irrigation in terms of AHTD removal [53-55] and comes with an increased risk of apical extrusion of the irrigant [56].

Instead, SAI causes a thorough mechanical agitation of the disinfectant in the root canal by "three-dimensional tip movement" [54]. Even though no cavitation effects are associated with sonic activation, both the tip oscillation and the microstreaming of the irrigant can loosen accumulated debris and pave the way for the irrigant to penetrate 
isthmuses and lateral canals [57]. The flexible and soft polyamide tip can move freely even in constrained and curved canals, and it enables sufficient disinfection without unwanted dentine preparation or alteration of the canal anatomy [17]. Although the efficiency can be controlled by the power settings of the sonic handpiece connected [58], caution must be exercised also with SAI because of the risk of instrument fracture [59] or apical irrigant extrusion causing postoperative pain [60-62].

In contrast to SAI, traditional passive ultrasonic irrigation (PUI) systems use rigid tips or endodontic files, which can cause dentine preparation during activation and may cause irregularities in the root canal surface $[25,63]$. The study deliberately included an innovative sonic-based system instead of PUI, because the efficiency of ultrasonic activation was reportedly limited in constrained root canals due to wall contact [64]. Although PUI is regarded as a gold standard, EDDY was reported to perform similarly in terms of debris removal $[21,54,65]$.

Another innovative method to activate the endodontic disinfectant during final irrigation is AutoSWEEPS. Here, a fiberglass tip is positioned in the access cavity to produce vapor bubbles, which advance into the root canal without alteration of the canal anatomy. Their collapse causes cavitation and photoacoustic streaming of the irrigant $[66,67]$. It is described that dual-pulse laser modalities, like AutoSWEEPS, combined with a flat fiberglass tip, as used in this study, show significantly more debris removal compared to single-pulse laser modalities in an ex-vivo-setting [68]. Another clinical advantage over sonic and ultrasonic instruments is the absent risk of instrument fracture $[59,69,70]$. However, the costs for purchase and consumption of laser-based systems are considerable. To our knowledge, no study exists so far that directly compared EDDY and AutoSWEEPS by $\mu \mathrm{CT}$-imaging for their ability to remove dentine debris from a complex root canal system.

Overall, the results of this study confirmed that CNI is inferior to SAI and LAI regarding hard tissue debris removal. After conventional needle irrigation, approximately $15 \%$ of the debris remained in the endodontic system, with up to $50 \%$ in the apical third, which is in line with previous studies [11,21,54]. In contrast to CNI, SAI with EDDY led to extensive removal of hard tissue debris in the coronal, middle and apical thirds of the root canals. Summarizing data from the three segments, a slight advantage over LAI was observed; however, there was no significant difference between sonic and laser activation in the individual root thirds.

LAI also enabled sufficient removal of accumulated artificial debris with a significant advantage over conventional needle irrigation. Remarkably, a few samples showed residual debris in the apical third of the root canals after LAI, which was not observed in any of the specimens after SAI. This finding may be related to the fact that compacted and solid debris in the apical region may be more difficult to remove, since there is no direct mechanical force with LAI. However, literature reports are controversial on this issue: Arslan et al. reported a superiority of laser-based PIPS over sonic-activated irrigation (EndoActivator) regarding the removal of artificial debris from artificial grooves in the apical third of root canals [71]. When compared to EDDY, PIPS delivered equal results for hard tissue debris removal [54]. As a further development of the laser-based systems, SWEEPS showed even better results in hard tissue debris removal compared to PIPS [32]. Furthermore, SWEEPS seemed to be advantageous over sonic activation with EndoActivator in terms of smear layer removal [72].

\section{Conclusions}

The implementation of an individual, 3D-printed model with a defined flow rate and the use of artificial debris enabled a reliable, reproducible and standardized assessment of the different irrigation methods. All techniques were able to remove artificial debris during final irrigation; however, SAI and LAI revealed a significantly higher reduction of hard tissue debris compared to CNI, especially in the apical third. 
Supplementary Materials: The following are available online at https: / www.mdpi.com/article/ 10.3390/app11167331/s1, Figure S1. Detailed construction plan of 3D-printed Irrigation Models. Figure S2. Schematic outline of the methodical workflow. Tables S1-S6. $p$-values adjusted familywise for multiple comparisons by the error rates method for all results.

Author Contributions: Conceptualization, M.W., L.K., R.S. and K.M.G.; methodology, M.W., L.K., B.S., R.J. and K.M.G.; software, L.K. and B.S.; formal analysis, L.K. and K.-A.H.; investigation, M.W., L.K. and R.S.; resources, B.S. and R.J.; data curation, M.W., L.K. and K.-A.H.; writing-original draft preparation, M.W. and L.K.; writing-review and editing, W.B. and K.M.G.; supervision, M.W. and K.M.G. All authors have read and agreed to the published version of the manuscript.

Funding: Funding was provided by the German Society of Dentistry and Oral Medicine (DGZMK) and the German Research Foundation (DFG-Nr. INST102।11-1 FUGG).

Institutional Review Board Statement: Not applicable.

Informed Consent Statement: Not applicable.

Data Availability Statement: All data are included in this study or in Supplementary Materials. Further details can be requested from the corresponding author.

Conflicts of Interest: The authors declare no conflict of interest.

\section{References}

1. Paqué, F.; Laib, A.; Gautschi, H.; Zehnder, M. Hard-Tissue Debris Accumulation Analysis by High-Resolution Computed Tomography Scans. J. Endod. 2009, 35, 1044-1047. [CrossRef]

2. Haapasalo, M.; Shen, Y.; Wang, Z.; Gao, Y. Irrigation in endodontics. Br. Dent. J. 2014, 216, 299-303. [CrossRef]

3. Meto, A.; Droboniku, E.; Blasi, E.; Colombari, B.; Tragaj, E.; Cervino, G.; Fiorillo, L.; Meto, A. Copper-Calcium Hydroxide and Permanent Electrophoretic Current for Treatment of Apical Periodontitis. Materials 2021, 14, 678. [CrossRef] [PubMed]

4. Peters, O.A.; Schönenberger, K.; Laib, A. Effects of four Ni-Ti preparation techniques on root canal geometry assessed by micro computed tomography. Int. Endod. J. 2001, 34, 221-230. [CrossRef] [PubMed]

5. Zhao, D.; Shen, Y.; Peng, B.; Haapasalo, M. Root canal preparation of mandibular molars with 3 nickel-titanium rotary instruments: A micro-computed tomographic study. J. Endod. 2014, 40, 1860-1864. [CrossRef]

6. Siqueira, J.F.; Pérez, A.R.; Marceliano-Alves, M.F.; Provenzano, J.C.; Silva, S.G.; Pires, F.R.; Vieira, G.C.S.; Rôças, I.N.; Alves, F.R.F. What happens to unprepared root canal walls: A correlative analysis using micro-computed tomography and histology/scanning electron microscopy. Int. Endod. J. 2018, 51, 501-508. [CrossRef]

7. Zehnder, M. Root Canal Irrigants. J. Endod. 2006, 32, 389-398. [CrossRef]

8. Ram, Z. Effectiveness of root canal irrigation. Oral Surgery Oral Med. Oral Pathol. 1977, 44, 306-312. [CrossRef]

9. Jiang, L.M.; Lak, B.; Eijsvogels, L.M.; Wesselink, P.; Van Der Sluis, L.W.M. Comparison of the cleaning efficacy of different final irrigation techniques. J. Endod. 2012, 38, 838-841. [CrossRef]

10. Blank-Gonalves, L.M.; Nabeshima, C.K.; Martins, G.H.R.; MacHado, M.E.D.L. Qualitative analysis of the removal of the smear layer in the apical third of curved roots: Conventional irrigation versus activation systems. J. Endod. 2011, 37, 1268-1271. [CrossRef]

11. Haupt, F.; Meinel, M.; Gunawardana, A.; Hülsmann, M. Effectiveness of different activated irrigation techniques on debris and smear layer removal from curved root canals: A SEM evaluation. Aust. Endod. J. 2020, 46, 40-46. [CrossRef]

12. Boutsioukis, C.; Lambrianidis, T.; Kastrinakis, E. Irrigant flow within a prepared root canal using various flow rates: A Computational Fluid Dynamics study. Int. Endod. J. 2009, 42, 144-155. [CrossRef]

13. Dioguardi, M.; Crincoli, V.; Sovereto, D.; Caloro, G.A.; Aiuto, R.; Illuzzi, G.; Caponio, V.C.A.; Troiano, G.; De Lillo, A.; Ciavarella, D.; et al. Effectiveness of Vapor Lock Effect Removal in Endo Training Blocks: Manual Dynamic Agitation versus Passive Ultrasonic Irrigation. Appl. Sci. 2019, 9, 5411. [CrossRef]

14. Gu, L.S.; Kim, J.R.; Ling, J.; Choi, K.K.; Pashley, D.H.; Tay, F.R. Review of Contemporary Irrigant Agitation Techniques and Devices. J. Endod. 2009, 35, 791-804. [CrossRef]

15. Jiang, L.M.; Verhaagen, B.; Versluis, M.; van der Sluis, L.W.M. Evaluation of a Sonic Device Designed to Activate Irrigant in the Root Canal. J. Endod. 2010, 36, 143-146. [CrossRef] [PubMed]

16. Van Der Sluis, L.W.M.; Versluis, M.; Wu, M.K.; Wesselink, P.R. Passive ultrasonic irrigation of the root canal: A review of the literature. Int. Endod. J. 2007, 40, 415-426. [CrossRef] [PubMed]

17. Neuhaus, K.W.; Liebi, M.; Stauffacher, S.; Eick, S.; Lussi, A. Antibacterial Efficacy of a New Sonic Irrigation Device for Root Canal Disinfection. J. Endod. 2016, 42, 1799-1803. [CrossRef]

18. De Gregorio, C.; Estevez, R.; Cisneros, R.; Heilborn, C.; Cohenca, N. Effect of EDTA, Sonic, and Ultrasonic Activation on the Penetration of Sodium Hypochlorite into Simulated Lateral Canals: An In Vitro Study. J. Endod. 2009, 35, 891-895. [CrossRef] [PubMed] 
19. Jensen, S.A.; Walker, T.L.; Hutter, J.W.; Nicoll, B.K. Comparison of the cleaning efficacy of passive sonic activation and passive ultrasonic activation after hand instrumentation in molar root canals. J. Endod. 1999, 25, 735-738. [CrossRef]

20. Rödig, T.; Bozkurt, M.; Konietschke, F.; Hülsmann, M. Comparison of the vibringe system with syringe and passive ultrasonic irrigation in removing debris from simulated root canal irregularities. J. Endod. 2010, 36, 1410-1413. [CrossRef]

21. Urban, K.; Donnermeyer, D.; Schäfer, E.; Bürklein, S. Canal cleanliness using different irrigation activation systems: A SEM evaluation. Clin. Oral Investig. 2017, 21, 2681-2687. [CrossRef] [PubMed]

22. Verstraeten, J.; Jacquet, W.; De Moor, R.J.G.; Meire, M.A. Hard tissue debris removal from the mesial root canal system of mandibular molars with ultrasonically and laser-activated irrigation: A micro-computed tomography study. Lasers Med. Sci. 2017, 32, 1965-1970. [CrossRef] [PubMed]

23. Walmsley, A.D.; Williams, A.R. Effects of constraint on the oscillatory pattern of endosonic files. J. Endod. 1989, 15, 189-194. [CrossRef]

24. Roy, R.A.; Ahmad, M.; Crum, L.A. Physical mechanisms governing the hydrodynamic response of an oscillating ultrasonic file. Int. Endod. J. 1994, 27, 197-207. [CrossRef]

25. Retsas, A.; Koursoumis, A.; Tzimpoulas, N.; Boutsioukis, C. Uncontrolled Removal of Dentin during In Vitro Ultrasonic Irrigant Activation in Curved Root Canals. J. Endod. 2016, 42, 1545-1549. [CrossRef]

26. Lea, S.C.; Felver, B.; Landini, G.; Walmsley, A.D. Ultrasonic scaler oscillations and tooth-surface defects. J. Dent. Res. 2009, 88, 229-234. [CrossRef]

27. Peters, O.A.; Bardsley, S.; Fong, J.; Pandher, G.; Divito, E. Disinfection of root canals with photon-initiated photoacoustic streaming. J. Endod. 2011, 37, 1008-1012. [CrossRef]

28. DiVito, E.; Peters, O.A.; Olivi, G. Effectiveness of the erbium: YAG laser and new design radial and stripped tips in removing the smear layer after root canal instrumentation. Lasers Med. Sci. 2012, 27, 273-280. [CrossRef]

29. Lloyd, A.; Uhles, J.P.; Clement, D.J.; Garcia-Godoy, F. Elimination of intracanal tissue and debris through a novel laser-activated system assessed using high-resolution micro-computed tomography: A pilot study. J. Endod. 2014, 40, 584-587. [CrossRef] [PubMed]

30. Lukač, N.; Muc, B.T.; Jezeršek, M.; Lukač, M. Photoacoustic Endodontics Using the Novel SWEEPS Er:YAG Laser modality. J. Laser Health Acad 2017, 1, 1-7.

31. Galler, K.M.; Grubmüller, V.; Schlichting, R.; Widbiller, M.; Eidt, A.; Schuller, C.; Wölflick, M.; Hiller, K.A.; Buchalla, W. Penetration depth of irrigants into root dentine after sonic, ultrasonic and photoacoustic activation. Int. Endod. J. 2019, 52, 1210-1217. [CrossRef]

32. Yang, Q.; Liu, M.W.; Zhu, L.X.; Peng, B. Micro-CT study on the removal of accumulated hard-tissue debris from the root canal system of mandibular molars when using a novel laser-activated irrigation approach. Int. Endod. J. 2020, 53, 529-538. [CrossRef]

33. Wang, X.N.; Shi, J. Shock wave-enhanced emission photoacoustic streaming versus photon-induced photoacoustic streaming modes for clearing root canal bacteria using erbium-doped yttrium aluminum garnet lasers: An in vitro study. BMC Oral Health 2019. preprint. [CrossRef]

34. Căpută, P.E.; Retsas, A.; Kuijk, L.; de Paz, L.E.C.; Boutsioukis, C. Ultrasonic Irrigant Activation during Root Canal Treatment: A Systematic Review. J. Endod. 2019, 45, 31-44. [CrossRef] [PubMed]

35. Rengo, C.; Spagnuolo, G.; Ametrano, G.; Juloski, J.; Rengo, S.; Ferrari, M. Micro-computerized tomographic analysis of premolars restored with oval and circular posts. Clin. Oral Investig. 2014, 18, 571-578. [CrossRef] [PubMed]

36. Riccitiello, F.; Amato, M.; Leone, R.; Spagnuolo, G.; Sorrentino, R. In vitro Evaluation of the Marginal Fit and Internal Adaptation of Zirconia and Lithium Disilicate Single Crowns: Micro-CT Comparison Between Different Manufacturing Procedures. Open Dent. J. 2018, 12, 160-172. [CrossRef] [PubMed]

37. Vertucci, F.J. Root canal anatomy of the human permanent teeth. Oral Surg. Oral Med. Oral Pathol. 1984, 58, 589-599. [CrossRef]

38. Widbiller, M.; Eidt, A.; Hiller, K.-A.; Buchalla, W.; Schmalz, G.; Galler, K.M. Ultrasonic activation of irrigants increases growth factor release from human dentine. Clin. Oral Investig. 2017, 21, 879-888. [CrossRef]

39. Widbiller, M.; Eidt, A.; Lindner, S.R.; Hiller, K.-A.; Schweikl, H.; Buchalla, W.; Galler, K.M. Dentine matrix proteins: Isolation and effects on human pulp cells. Int. Endod. J. 2018, 51, 278-290. [CrossRef]

40. Zorzin, J.; Wießner, J.; Wießner, T.; Lohbauer, U.; Petschelt, A.; Ebert, J. Removal of radioactively marked calcium hydroxide from the root canal: Influence of volume of irrigation and activation. J. Endod. 2016, 42, 637-640. [CrossRef]

41. Cruz, A.; Vera, J.; Gascón, G.; Palafox-Sánchez, C.A.; Amezcua, O.; Mercado, G. Debris remaining in the apical third of root canals after chemomechanical preparation by using sodium hypochlorite and glyde: An in vivo study. J. Endod. 2014, 40, 1419-1423. [CrossRef]

42. Robinson, J.P.; Lumley, P.J.; Cooper, P.R.; Grover, L.M.; Walmsley, A.D. Reciprocating root canal technique induces greater debris accumulation than a continuous rotary technique as assessed by 3-dimensional micro-computed tomography. J. Endod. 2013, 39, 1067-1070. [CrossRef] [PubMed]

43. Lee, S.J.; Wu, M.K.; Wesselink, P.R. The efficacy of ultrasonic irrigation to remove artificially placed dentine debris from different-sized simulated plastic root canals. Int. Endod. J. 2004, 37, 607-612. [CrossRef] [PubMed]

44. Van Der Sluis, L.W.M.; Wu, M.K.; Wesselink, P.R. The efficacy of ultrasonic irrigation to remove artificially placed dentine debris from human root canals prepared using instruments of varying taper. Int. Endod. J. 2005, 38, 764-768. [CrossRef] 
45. Kurzmann, C.; Meire, M.A.; Lettner, S.; Farmakis, E.T.R.; Moritz, A.; De Moor, R.J.G. The efficacy of ultrasonic and PIPS (photon-induced acoustic streaming) irrigation to remove artificially placed dentine debris plugs out of an artificial and natural root model. Lasers Med. Sci. 2020, 35, 719-728. [CrossRef] [PubMed]

46. Wiseman, A.; Cox, T.C.; Paranjpe, A.; Flake, N.M.; Cohenca, N.; Johnson, J.D. Efficacy of sonic and ultrasonic activation for removal of calcium hydroxide from mesial canals of mandibular molars: A microtomographic study. J. Endod. 2011, 37, 235-238. [CrossRef] [PubMed]

47. De Oliveira, R.L.; Guerisoli, D.M.Z.; Duque, J.A.; Alcalde, M.P.; Onoda, H.K.; Domingues, F.H.F.; Vivan, R.R.; Duarte, M.A.H. Computed microtomography evaluation of calcium hydroxide-based root canal dressing removal from oval root canals by different methods of irrigation. Microsc. Res. Tech. 2019, 82, 232-237. [CrossRef] [PubMed]

48. Silva, E.J.N.L.; Carvalho, C.R.; Belladonna, F.G.; Prado, M.C.; Lopes, R.T.; De-Deus, G.; Moreira, E.J.L. Micro-CT evaluation of different final irrigation protocols on the removal of hard-tissue debris from isthmus-containing mesial root of mandibular molars. Clin. Oral Investig. 2019, 23, 681-687. [CrossRef]

49. Leoni, G.B.; Versiani, M.A.; Silva-Sousa, Y.T.; Bruniera, J.F.B.; Pécora, J.D.; Sousa-Neto, M.D. Ex vivo evaluation of four final irrigation protocols on the removal of hard-tissue debris from the mesial root canal system of mandibular first molars. Int. Endod. J. 2017, 50, 398-406. [CrossRef]

50. Cesario, F.; Duarte, M.A.H.; Duque, J.A.; Alcalde, M.P.; De Andrade, F.B.; So, M.V.R.; De Vasconcelos, B.C.; Vivan, R.R. Comparisons by microcomputed tomography of the efficiency of different irrigation techniques for removing dentinal debris from artificial grooves. J. Conserv. Dent. 2018, 21, 383-387. [CrossRef]

51. Huang, T.Y.; Gulabivala, $\mathrm{K}$; $\mathrm{Ng}$, Y.L. A bio-molecular film ex-vivo model to evaluate the influence of canal dimensions and irrigation variables on the efficacy of irrigation. Int. Endod. J. 2008, 41, 60-71. [CrossRef] [PubMed]

52. Gulabivala, K.; Ng, Y.-L.; Gilbertson, M.; Eames, I. The fluid mechanics of root canal irrigation. Physiol. Meas. 2010, 31, 49-84. [CrossRef]

53. Donnermeyer, D.; Wyrsch, H.; Bürklein, S.; Schäfer, E. Removal of Calcium Hydroxide from Artificial Grooves in Straight Root Canals: Sonic Activation Using EDDY Versus Passive Ultrasonic Irrigation and XPendo Finisher. J. Endod. 2019, 45, 322-326. [CrossRef] [PubMed]

54. Swimberghe, R.C.D.; De Clercq, A.; De Moor, R.J.G.; Meire, M.A. Efficacy of sonically, ultrasonically and laser-activated irrigation in removing a biofilm-mimicking hydrogel from an isthmus model. Int. Endod. J. 2019, 52, 515-523. [CrossRef] [PubMed]

55. Hage, W.; De Moor, R.J.G.; Hajj, D.; Sfeir, G.; Sarkis, D.K.; Zogheib, C. Impact of Different Irrigant Agitation Methods on Bacterial Elimination from Infected Root Canals. Dent. J. 2019, 7, 64. [CrossRef]

56. Boutsioukis, C.; Psimma, Z.; Kastrinakis, E. The effect of flow rate and agitation technique on irrigant extrusion ex vivo. Int. Endod. J. 2014, 47, 487-496. [CrossRef]

57. Macedo, R.G.; Verhaagen, B.; Rivas, D.F.; Versluis, M.; Wesselink, P.; Van Der Sluis, L. Cavitation measurement during sonic and ultrasonic activated irrigation. J. Endod. 2014, 40, 580-583. [CrossRef]

58. Eggmann, F.; Vokac, Y.; Eick, S.; Neuhaus, K.W. Sonic irrigant activation for root canal disinfection: Power modes matter! BMC Oral Health 2020, 20, 102. [CrossRef]

59. Kirsch, J.; Sina Reinauer, K.; Meissner, H.; Dannemann, M.; Kucher, M.; Modler, N.; Hannig, C.; Weber, M.-T. Ultrasonic and sonic irrigant activation in endodontics: A fractographic examination. Dtsch. Zahnärztl Z. Int. 2019, 1, 209-221. [CrossRef]

60. Pashley, E.L.; Birdsong, N.L.; Bowman, K.; Pashley, D.H. Cytotoxic effects of NaOCl on vital tissue. J. Endod. 1985, 11, 525-528. [CrossRef]

61. Gernhardt, C.R.; Eppendorf, K.; Kozlowski, A.; Brandt, M. Toxicity of concentrated sodium hypochlorite used as an endodontic irrigant. Int. Endod. J. 2004, 37, 272-280. [CrossRef] [PubMed]

62. Hülsmann, M.; Hahn, W. Complications during root canal irrigation-Literature review and case reports. Int. Endod. J. 2000, 33, 186-193. [CrossRef]

63. Boutsioukis, C.; Tzimpoulas, N. Uncontrolled Removal of Dentin during in Vitro Ultrasonic Irrigant Activation. J. Endod. 2016, 42, 289-293. [CrossRef]

64. Boutsioukis, C.; Verhaagen, B.; Walmsley, A.D.; Versluis, M.; Van Der Sluis, L.W.M. Measurement and visualization of file-to-wall contact during ultrasonically activated irrigation in simulated canals. Int. Endod. J. 2013, 46, 1046-1055. [CrossRef] [PubMed]

65. Plotino, G.; Grande, N.M.; Mercade, M.; Cortese, T.; Staffoli, S.; Gambarini, G.; Testarelli, L. Efficacy of sonic and ultrasonic irrigation devices in the removal of debris from canal irregularities in artificial root canals. J. Appl. Oral Sci. 2019, 27, e20180045. [CrossRef]

66. Lukač, N.; Jezeršek, M. Amplification of pressure waves in laser-assisted endodontics with synchronized delivery of Er:YAG laser pulses. Lasers Med. Sci. 2018, 33, 823-833. [CrossRef] [PubMed]

67. Ohl, C.-D.; Arora, M.; Dijkink, R.; Janve, V.; Lohse, D. Surface cleaning from laser-induced cavitation bubbles. Appl. Phys. Lett. 2006, 89, 074102. [CrossRef]

68. Jezeršek, M.; Lukač, N.; Lukač, M. Measurement of Simulated Debris Removal Rates in an Artificial Root Canal to Optimize Laser-Activated Irrigation Parameters. Lasers Surg. Med. 2021, 53, 411-417. [CrossRef] [PubMed]

69. Parashos, P.; Messer, H.H. Rotary NiTi Instrument Fracture and its Consequences. J. Endod. 2006, 32, 1031-1043. [CrossRef]

70. Mcguigan, M.B.; Louca, C.; Duncan, H.F. The impact of fractured endodontic instruments on treatment outcome. Br. Dent. J. 2013, 214, 285-289. [CrossRef] 
71. Arslan, H.; Capar, I.D.; Saygili, G.; Gok, T.; Akcay, M. Effect of photon-initiated photoacoustic streaming on removal of apically placed dentinal debris. Int. Endod. J. 2014, 47, 1072-1077. [CrossRef] [PubMed]

72. Mancini, M.; Cerroni, L.; Palopoli, P.; Olivi, G.; Olivi, M.; Buoni, C.; Cianconi, L. FESEM evaluation of smear layer removal from conservatively shaped canals: Laser activated irrigation (PIPS and SWEEPS) compared to sonic and passive ultrasonic activation-an ex vivo study. BMC Oral Health 2021, 21, 81. [CrossRef] [PubMed] 